\title{
Etika praktik product placement dalam film Ayat-Ayat Cinta 2
}

\author{
Kismiyati El Karimah ${ }^{1}$, Putri Intan Ewie Syafitri ${ }^{2}$, Uud Wahyudin ${ }^{3}$ \\ 1,2,3 Universitas Padjadjaran, Bandung, Indonesia
}

\begin{abstract}
ABSTRAK
Product placement sudah tidak dapat dihindari dari perfilman Indonesia karena dibutuhkan untuk membantu biaya produksi film. Namun, product placement terkadang terlalu berlebihan sehingga dapat mengganggu cerita. Salah satu film Indonesia yang mengandung product placement yang cukup banyak serta memaksa, yaitu Ayat-Ayat Cinta 2. Film ini menyisipkan berbagai iklan produk dan/atau merek dalam beberapa adegan yang dapat mengaburkan makna produk dan film. Penelitian ini bertujuan untuk mengetahui bagaimana praktik product placement yang terdapat dalam film Ayat-Ayat Cinta 2 dilakukan. Metode penelitian yang digunakan oleh peneliti adalah metode penelitian kualitatif dengan pendekatan analisis semiotika Roland Barthes di mana pada tataran pertama dan kedua dibandingkan dengan peraturan dan etika product placement dalam periklanan. Analisis ini dapat mengidentifikasi makna denotatif, makna konotatif, dan mitos pada setiap adegan yang menampilkan product placement, maka dapat dilihat apakah praktik yang dilakukan sesuai atau tidak dengan etika beriklan. Hasil dari penelitian ini menunjukkan bahwa makna denotatif menjadi pengabur ketika makna dan konteks tidak saling berkaitan. Sedangkan makna konotatif menjadi pengabur ketika makna adegan yang disisipi iklan sponsor mengalami perubahan makna. Mitos menjadi pengabur ketika positioning produk yang ditampilkan tidak sesuai dengan fakta produk yang sebenarnya.
\end{abstract}

Kata Kunci: product placement; etika; film; denotasi; konotasi; mitos

\section{Ethics of product placement practice in Ayat-Ayat Cinta 2}

\begin{abstract}
Product placement is an usual thing in Indonesia film industry. Advertisement in film is neded to support production. But, nowadays product placement is a bit overrated that can make a bias for some plots. There is an Indonesia film that contains much product placements, that's Ayat-Ayat Cinta 2. This film contains some of product and lor brand advertisements in several scenes so that it can obscure the meaning of the product and film. This research was an attempt to find out how the practice of product placement contained in Ayat-Ayat Cinta 2. The research method used by researchers is a qualitative research method using Roland Barthes's semiotic analysis in which at the first and second levels compare with the regulations and ethics of product placement in advertising. Roland Barthes's semiotic analysis can help in reducing the distorted meaning of the product placement activity to see which scenes are appropriate and not according to the ethics of advertising. By looking at denotative meanings, connotative meanings, and myths in each scene that displays product placement, it can be seen whether the practices carried out are appropriate or not with the ethics of advertising. The result in this study shows that denotative meaning becomes blurred when meaning and context are not interrelated, while connotative meaning becomes blurred when the meaning of the scene inserted by the sponsor ad changes meaning. Mythical meaning becomes blurred when the product positioning displayed is not in accordance with the actual product facts.
\end{abstract}

Keywords: product placement; ethics; film; denotation; connotation; myth

Korespondensi: Kismiyati El Karimah, M.Si. Universitas Padjadjaran. Jalan Raya Bandung-Sumedang Km 21 Jatinangor 45363 Jawa Barat. Email: kismiyati@unpad.ac.id 


\section{PENDAHULUAN}

Iklan adalah salah satu jenis promosi yang paling sering dijumpai dan digunakan oleh perusahaan dalam memasarkan merek maupun produknya (Hidayat, 2015). Namun, di tengah kemajuan teknologi dan informasi pada saat ini memaksa perusahaan untuk lebih cermat dalam memilih media beriklan. Salah satu media konvensional, seperti media cetak semakin ditinggalkan oleh masyarakat sehingga perusahaan memilih untuk menggunakan media elektronik maupun media online dalam melakukan iklan.

Salah satu media elektronik yang dijadikan tempat beriklan adalah televisi. Dalam hal ini, televisi memiliki suatu kelebihan jika dibandingkan dengan media cetak karena memilki kemampuan audio-visual dan menjangkau penonton dalam jumlah besar dan waktu yang bersamaan (Mirandha, 2017). Iklan pada televisi terletak di antara sela-sela tayangan sebuah acara. Menurut data dari Lowe pada tahun 2005, perusahaan komunikasi Indonesia, $53 \%$ pemirsa atau penonton mengganti saluran televisi saat iklan. Hal ini menunjukkan bahwa lebih dari 50\% penonton di Indonesia melakukan zapping dan zipping, yaitu suatu keadaan di mana penonton melakukan penggantian saluran televisi (Mellawatie, Maryani, \& Aristi, 2017).

Kondisi ini menunjukkan bahwa adanya persaingan yang timbul karena fragmentasi media dan khalayak yang semakin tinggi. Distraksi ini semakin melebar karena ketidakpastian dari pola konsumsi media yang semakin oportunis. Penonton dapat dengan mudah mengganti channel ketika iklan sedang ditayangkan di televisi dan memilih untuk menonton program atau acara televisi lain yang sedang tayang (Hidayat, 2015; Nuraryo, 2019).

Perubahan ini membuat perusahaan mencari alternatif lain untuk mempromosikan merek dan/atau produknya kepada khalayak dalam jumlah besar dan tepat sasaran. Caranya adalah dengan melakukan penempatan produk atau product placement. Istilah ini juga bisa disebut penyisipan produk. Penempatan atau penyisipan produknya pun bisa jadi berbedabeda, tetapi tujuan utamanya tetap untuk meraih brand recall dan meningkatkan brand image (Bressoud \& Lehu, 2008)

Meskipun product placement di Indonesia awalnya diterapkan dalam film, tetapi dalam perkembangannya, untuk mendapatkan ruang iklan kembali, praktik ini sudah dilakukan oleh para perusahaan melalui televisi sejak sepuluh tahun terakhir. Produk biasanya disisipkan dalam sebuah acara variety show, seperti Indonesian Idol, Mamma Mia, The Voice Indonesia, dan lain sebagainya. Acara ini menyisipkan produk dan/atau merek sponsor pada saat tayangan 
sedang berlangsung. Produk dan/atau merek itu ditampilkan dalam bentuk banner atau iklan berjalan maupun menjadi properti dalam acara tersebut.

Bukanitu saja, dalam tiga tahun terakhirjuga ditemukan bahwa praktik ini telah memasuki siaran sinetron di Indonesia. Penempatan produk ini sebagian besar menyisipkan iklan provider yang biasanya ditampilkan di papan billboard atau baligho yang muncul di tengah adegan dalam sinetron. Hal ini menunjukkan bahwa praktik ini berhasil menjadi jalan keluar dari zipping dan zapping yang menjadi permasalahan promosi produk dan/atau merek suatu perusahaan (Kumalawati, Leonid, \& Rumambi, 2012).

Praktik product placement di Indonesia sudah mulai dilakukan pada dekade 80-an. Pada saat itu, praktik product placement di Indonesia dilakukan dengan cara menyisipkan produk sponsor di dalam film. Film menjadi salah satu media utama product placement karena memiliki sasaran audiens yang sudah tersegmentasi (Kumalawati et al., 2012). Film Indonesia pertama yang menerapkan product placement adalah film CHIPS pada tahun 1982 dan disusul dengan Catatan Si Boy pada tahun 1987. Seiring dengan bangkitnya kembali perfilman nasional di akhir dekade 90-an, praktik product placement kembali muncul dalam film Tusuk Jelangkung pada tahun 2002.
Film ini menampilkan beberapa produk, seperti Honda Stream, telepon genggam Samsung, dan minuman Berry Juice (Marketing.co.id, 2012). Praktik ini pun terus berjalan hingga sekarang. Adapun beberapa film Indonesia yang juga melakukan penempatan produk, yaitu film Critical Eleven yang menempatkan jasa LINEpay pada adegan membayar makan di sebuah restoran, kehadiran produk Gery Chocolatos, Wardah, dan e-TOL dengan time-frame yang tidak sesuai pada film Habibie \& Ainun, serta Indomie pada film $5 \mathrm{CM}$.

Penelitian sebelumnya yang juga membahas tentang product placement dalam film, yaitu "Representasi Product Placement dalam Film Habibie dan Ainun" mengkritisi tentang visualisasi produk dalalam adegan film dan ketidaksesuain time-frame produk dapat memberikan pengaruh yang berbeda bagi posiioning produk (Primalia, 2006). Analisisnya menunjukkan bahwa product placement mengakibatkan adanya keterbatasan produk dalam memberikan gambaran untuk merepresentasikan positioning produk. Selain itu, product placement juga memengaruhi penilaian penonton terhadap 'realita' yang ditampilkan dan membuat penonton mempertanakan kredibilitas dari makna-makna yang direpresentasikan dalam film Habibie dan Ainun.

Kehadiran produk atau merek dalam 
sebuah film sebenarnya berfungsi sebagai penguat realisme dalam film. Produk yang dulunya tampil tanpa label merek sekarang telah digantikan dengan label yang otentik. Dengan begitu, penonton akan merasa dekat dengan film yang sedang ditonton karena produk yang dilihat dapat ditemukan dalam kehidupan sehari-hari. Selain itu, bagi pembuatan film yang membutuhkan biaya produksi yang cukup besar, sokongan dana dari penempatan suatu produk dapat meringankan biaya produksi. Namun, batasan antara hiburan dan promosi menjadi kabur sejak praktik ini berkembang dari metode yang awalnya hanya sekadar “menunjukkan kaleng” menjadi bagian integral dari cerita (Hackley \& Nappolini, 2008). Hal inilah yang mengawali perdebatan mengenai etis atau tidaknya praktik product placement.

Masalah yang muncul di sini adalah pengaruh adanya sisipan produk terhadap teks film serta kenyataan bahwa konsumen tidak sadar jika mereka telah dibombardir oleh iklan ketika mereka sedang menonton film. Oleh karena itu, kekuatan akan pengaruh film dan iklan menimbulkan suatu kritik bahwa hal ini dapat menyebabkan orang-orang mengasosiasikan produk dan/atau merek dengan aktor film dan membeli produk atau jasa yang tidak mereka butuhkan. Iklan juga dinilai sebagai tindakan manipulatif yang mempunyai kekuatan untuk memengaruhi orang untuk berperilaku tidak umum atau melakukan sesuatu yang tidak akan mereka lakukan jika tidak ditunjukkan oleh iklan. Pada perilaku ekstrem, hal ini menunjukkan bahwa iklan mampu menggerakkan orang melawan keinginan bebas mereka sendiri (Shimp, 2014).

\section{Product placement merupakan suatu stealth}

advertising karena secara esensial penonton tidak menyadari adanya unsur promosi dalam film yang disaksikan, bahkan dianggap sebagai bagian dari adegan film (Tandiono \& Rumambi, 2013). Dalam hal ini, produsen mengharapkan seolah secara tidak sengaja penonton dapat mengidentifikasi keberadaan produk dengan sendirinya melalui penggambarannya dalam scene, positioning produk dapat dikomunikasikan kepada penonton. Dalam praktiknya, metode ini berusaha mencapai tujuannya tanpa membiarkan orang mengetahui bahwa mereka sedang menjadi target. Ini yang menjadi permasalahan etis karena metode ini didesain untuk "menipue orang agar memerhatikan iklan.

Dijelaskan bahwa penempatan produk merupakan salah satu yang dilakukan oleh rumah produksi film untuk meringankan biaya produksi. Dengan memasukkan produk sponsor ke dalam film akan menjadi hal yang saling menguntungkan bagi kedua belah pihak. Pihak produksifilm mendapat bantuan dana, sedangkan sponsor dapat menampilkan produknya kepada 
sasaran yang tepat (Purnomo, 2015).

Sponsor dapat disebut sebagai pengiklan. Sponsor atau pengiklan inilah yang bertindak sebagai pemodal (Sasono, 2011). Pemilik modal dalam ekonomi memiliki kuasa untuk mengatur. Sama halnya dengan kapitalisme, kekuatan hanya dimiliki oleh segelintir orang yang memiliki modal kuat. Dalam sistem ekonomi, kapitalisme menempatkan kebebasan kepemilikan sebagai motor penggerak perekonomiannya.

Uraian tersebut menunjukkan bahwa perusahaan pengiklan dan rumah produksi film secara diam-diam menetapkan paham atau ideologi kapitalisme untuk mencapai tujuannya. Kedua pihak sama-sama mencari jalan keluar untuk mewujudkan kepentingannya meskipun melanggar beberapa nilai dan etika dalam beriklan.

Perilaku etis merupakan suatu tindakan yang sesuai dengan etika atau nilai-nilai yang disepakati secara umum. Sesuatu yang dianggap etis berarti suatu tindakan yang patuh terhadap etika. Etika sendiri merupakan sesuatu yang berkaitan dengan komponen kehidupan moral manusia. Etika dapat merefleksikan gagasan masyarakat mengenai suatu hal yang benar dan salah, serta perbedaan antara baik dan buruk. Etika juga memasukkan evaluasi dan aplikasi nilai moral yang telah diterima oleh masyarakat sebagai norma (Day, 2006).
Berdasarkan penjelasan tersebut, apabila dikaitkan dengan perilaku etis dalam beriklan, berarti segala sesuatunya harus patuh dengan norma masyarakat. Hal ini bukan bertujuan untuk membuat batasan etis yang harus disetujui oleh setiap orang, tetapi untuk membuat batasan yang sesuai dengan harapan sosial. Maka dari itu, jika dikaitkan dengan batas etis beriklan, norma masyarakat juga harus berkesinambungan dengan peraturan yang telah ditetapkan secara hukum.

Untuk mengatur jalannya periklanan di Indonesia, terdapat suatu peraturan yang terdapat dalam kitab Etika Pariwara Indonesia (Dewan Periklanan Indonesia, 2007, 2014). Dalam EPI Amandemen 2014 butir 39 tertulis bahwa penyisipan produk atau product placement harus menyatu dengan cerita. Selain itu, pada butir 4.4 .9 tertulis bahwa "iklan tersisip oleh penaja harus disajikan sedemikian rupa sehingga tidak mengganggu kenyamanan penonton." Dengan demikian, tersirat bahwa dalam mengiklankan produk dalam film harus melihat dari segi kepantasannya. Hal tersebut dapat dilihatdariketerkaitan produk denganjalan cerita, ketersediaan produk, serta fakta produk. Meskipun telah diatur dalam EPI, pengiklan dan rumah produksi film selalu mencari celah di mana mereka dapat menjalankan praktik product placement agar terlihat etis.

Pada akhir 2017 lalu, ada sebuah film 
yang menarik perhatian publik. Film ini adalah Ayat-Ayat Cinta 2. Ayat-Ayat Cinta bagian pertama tayang di bioskop pada tahun 2008 lalu sukses mencapai 3,5 juta penonton. Film ini diadaptasi dari novel Habiburrahman El Shirazy dan diproduksi oleh MD Pictures. Karena kesuksesannya, Ayat-Ayat Cinta memiliki kisah lanjutan mengenai perjalanan Fahri dan Aisyah. Mengikuti kesuksesan film pertama, menurut filmindonesia.or.id, Ayat-Ayat Cinta 2 yang mulai tayang pada 21 Desember 2017 menembus satu juta penonton dalam lima hari penayangan. ${ }^{3}$ Selain menyuguhkan drama antara pemainnya, ternyata terdapat praktik product placement dalam film ini. Setidaknya ada delapan merek yang disisipkan di film ini, antara lain Wardah, Toyota, Milky, Simpati, Singapore Airlines, Samsung, MOX, dan Twinings.

Sayangnya, penempatan produk pada film Ayat-Ayat Cinta 2 ini terkesan memaksa, tidak sesuai dengan logika setting film serta positioning produk. Contohnya, pengambilan gambar secara full shot terhadap bedak Wardah, munculnya baligho provider Simpati di luar konteks film, serta adegan swafoto menggunakan Samsung smartphone secara tiba-tiba. Hal ini menunjukkan adanya suatu pemaksaan dalam memasukkan suatu kepentingan dari pihak tertentu. Melalui penelitian ini, peneliti akan mengidentifikasi bagaimana praktik penempatan produk dilakukan dalam film AyatAyat Cinta 2. Pendekatan yang akan digunakan adalah analisis semiotika Roland Barthes yang dapat menganalisis makna dari tanda-tanda. Fokus perhatian Barthes, menurut Fiske lebih tertuju kepada gagasan tentang signifikasi dua tahap (two order of signification) (Alex Sobur, 2006).

Signifikasi tahap pertama merupakan hubungan penanda (signifier) dan petanda (signified) di dalam sebuah tanda terhadap realitas eksternal. Barthes menyebutnya sebagai denotasi, yaitu makna yang paling nyata dari tanda. Sedangkan untuk menunjukkan signifikasi tahap kedua, Barthes menggunakan konotasi yang menggambarkan interaksi yang terjadi ketika tanda bertemu dengan perasaan atau emosi dari pembaca serta nilai-nilai dari kebudayaannya. Sedangkan pada signifikasi tahap kedua yang berhubungan dengan isi, tanda bekerja melalui mitos, yaitu bagaimana kebudayaan menjelaskan atau memahami beberapa aspek tentang realitas atau gejala alam.

Olehkarenaitu,pemeriksaaniniakanditelaah dengan melakukan analisis komprehensif terhadap hal-hal yang berpengaruh terhadap penafsiran teks untuk melihat makna denotatif, makna konotatif, dan mitos dalam praktik penempatan produk dalam film Ayat-Ayat Cinta 2 ini. Penelitian ini bukan untuk menjelaskan 
ideologi yang ingin ditanamkan suatu product placement melalui makna denotasi, konotasi, dan mitos. Dengan melihat makna denotasi, konotasi, dan mitos serta kaitannya terhadap adegan tertentu, penelitian ini ingin menunjukkan adanya suatu "pemaksaan" yang dilakukan oleh pengiklan dan rumah produksi film karena adanya beberapa kepentingan yang harus mereka penuhi. Dengan begitu, kita dapat melihat bagaimana penanda dan petanda dapat mendistorsi makna suatu objek sehingga dapat mengaburkan batas etis dalam iklan.

Tujuan penelitian ini adalah untuk memaparkan representasi product placement dalam film Ayat-Ayat Cinta 2 sebagai bentuk kaburnya batas etis dalam iklan, dengan tiga pertanyaan penelitian yang mencari tahu makna denotatif, makna konotatif, dan mitos pada praktik product placement dalam film Ayat-Ayat Cinta 2 dan kaitannya dengan etika beriklan.

\section{METODE PENELITIAN}

Metode yang digunakan dalam penelitian ini berupa metode kualitatif. Adapun yang dimaksud dengan metode penelitian kualitatif menurut Bogdan dan Taylor mendefinisikan "metodologi kualitatif" sebagai prosedur penelitian yang menghasilkan data deskriptif berupa kata-kata tertulis atau lisan dari orang-orang dan perilaku yang dapat diamati (Moleong, 2008).
Penelitian ini menganalisis media film sebagai teks. Dalam analisis media sebagai teks, seorang peneliti memiliki kebebasan dan otonomi penuh untuk menafsirkan atas sebuah teks. Yang jadi masalah bukan benar tidaknya tafsiran yang diberikan, tetapi argumentasi yang dijadikan landasan dalam memberikan penafsiran serta kedekatanya dengan fenomena yang terjadi dan berkaitan dengan teks tersebut (Bungin, 2011).

Metode penelitian yang digunakan oleh peneliti adalah metode penelitian kualitatif dengan pendekatan analisis semiotika Roland Barthes. Pendekatan ini berupaya mengupas dengan cara melihat reduksi dan distorsi makna produk dalam praktik product placement sehingga dapat memberikan gambaran mengenai etis atau tidaknya praktik ini dalam film Ayat-Ayat Cinta 2.

Dalam pemikiran Ferdinand Saussure, yang paling penting dalam konteks semiotik adalah pandangannya mengenai tanda. Saussure membagi konteks komunikasi manusia antara signifier (penanda) dan signified (petanda). Signifier adalah bunyi yang bermakna atau coretan yang bermakna (aspek material), yaitu apa yang dikatakan dan apa yang ditulis atau dibaca. Signified adalah gambaran mental, yaitu pikiran atau konsep aspek mental dari bahasa (Alex Sobur, 2006b)

Roland Barthes membuat sebuah model 


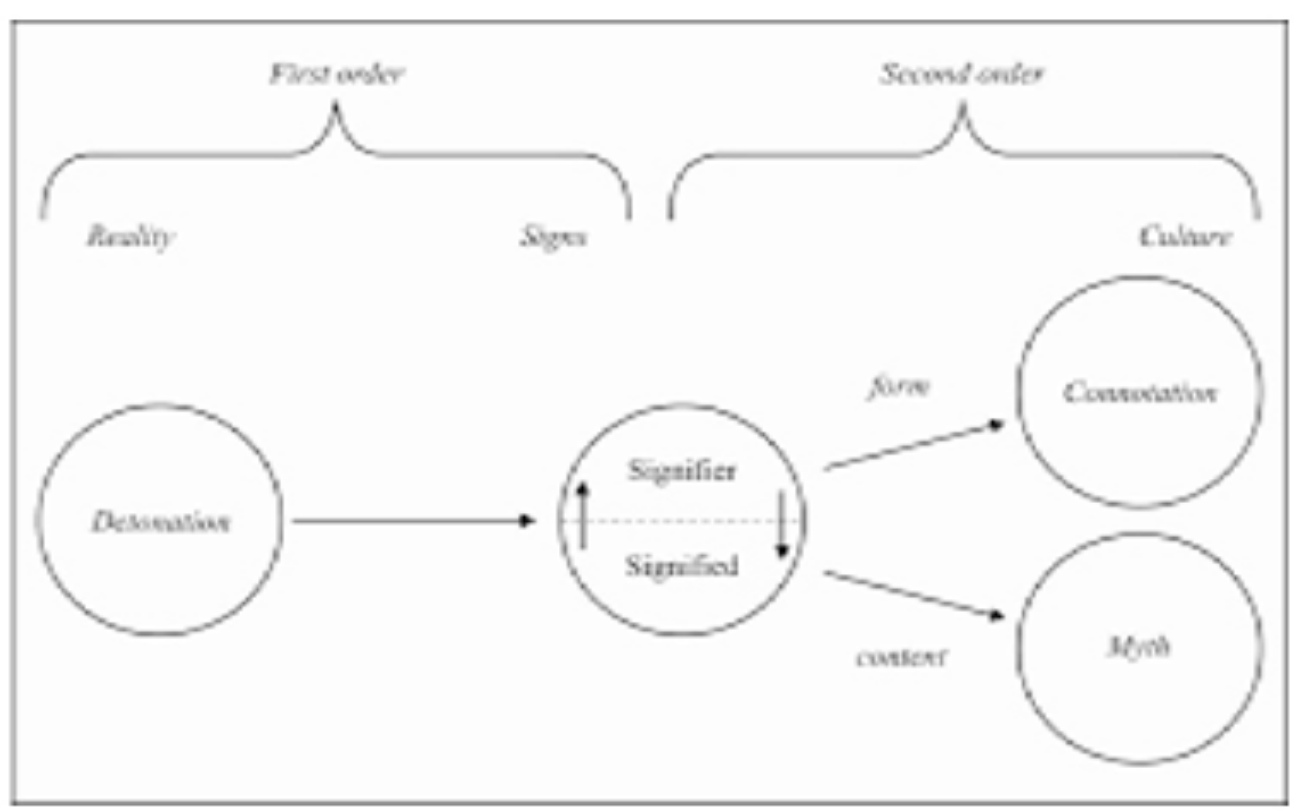

Sumber: Sobur, 2006

\section{Gambar 1. Signifikasi Dua Tahap Barthes}

sistematis dalam menganalisis makna dari tanda-tanda yang merupakan kelanjutan dan perkembangan dari pemikiran Saussure. Fokus perhatian Barthes lebih tertuju kepada gagasan tentang signifikasi dua tahap (two order of signification).

Dari gambar 1 menjelaskan: signifikasi tahap pertama merupakan hubungan antara signifier dan signified di dalam sebuah tanda terhadap realitas eksternal. Barthes menyebutnya sebagai denotasi, yaitu makna paling nyata dari tanda. Konotasi adalah istilah yang digunakan Barthes untuk menunjukkan signifikasi tahap kedua. Hal ini menggambarkan interaksi yang terjadi ketika tanda bertemu dengan perasaan atau emosi dari pembaca serta nilai-nilai dari kebudayaannya. Konotasi mempunyai makna yang subjektif atau paling tidak intersubjektif.

Konotasi bekerja dalam tingkat subjektif sehingga kehadirannya tidak disadari. Pembaca mudah sekali membaca makna konotatif sebagai makna denotatif. Oleh karena itu, salah satu tujuan analisis semiotik adalah untuk menyediakan metode analisis dan kerangka berpikir untuk mengatasi salah baca (misreading).

Pada signifikasi tahap kedua yang berhubungan dengan isi, tanda bekerja melalui mitos (myth). Mitos adalah bagaimana kebudayaan menjelaskan atau memahami beberapa aspek tentang realitas atau gejala alam. Mitos merupakan produk kelas sosial yang sudah mempunyai suatu dominasi. Mitos primitif, misalnya, mengenai hidup dan mati, manusia dan dewa, dan sebagainya. Sedangkan mitos masa kini, misalnya mengenai femininitas, masklulinitas, ilmu pengetahuan, dan kesuksesan (Alex Sobur, 2006). 


\begin{tabular}{|c|c|}
\hline $\begin{array}{c}\text { 1.Signifier } \\
\text { (penanda) }\end{array}$ & $\begin{array}{c}\text { 2.Signified } \\
\text { (petanda) }\end{array}$ \\
\cline { 1 - 1 } $\begin{array}{c}\text { 3.denotatif sign } \\
\text { (tanda denotatif) }\end{array}$ \\
\hline $\begin{array}{c}\text { 4.CONNOTATIVE SIGNIFIER } \\
\text { (PENANDA KONOTATIF) }\end{array}$ & $\begin{array}{c}\text { S.CONNOTATIVE SIGNIFIED } \\
\text { (PETANDA KONOTATIF) }\end{array}$ \\
\hline \multicolumn{2}{|c|}{ 6.CONNOTATIVE SIGN (TANDA KONOTATIF) } \\
\hline
\end{tabular}

Sumber: Sobur, 2006

\section{Gambar 2. Peta Tanda Roland Barthes}

Dari peta tanda Barthes pada gambar 2 terlihat bahwa tanda denotatif (3) terdiri atas penanda (1) dan petanda (2). Akan tetapi, pada saat yang bersamaan, tanda denotatif adalah juga penanda konotatif (4). Dengan kata lain, Cobley dan Jansz menyatakan hal tersebut merupakan unsur material: hanya jika Anda mengenal tanda "singa", barulah konotasi seperti harga diri, kegarangan, dan keberanian menjadi mungkin (Alex Sobur, 2006). Jadi, dalam konsep Barthes, tanda konotatif tidak sekadar memiliki makna tambahan, tetapi juga mengandung kedua bagian tanda denotatif yang melandasi keberadaannya. Tujuan analaisis Barthes bukan hanya untuk membangun suatu sistem klasifikasi unsur-unsur narasi yang sangat formal, tetapi lebih banyak untuk menunjukkan bahwa tindakan yang paling masuk akal, rincian yang paling meyakinkan, atau teka-teki yang paling menarik, merupakan produk buatan, dan bukan tiruan dari yang nyata (Lechte, 2001).

\section{HASIL DAN PEMBAHASAN}

Peneliti mengidentifikasi tentang bagaimana tanda bekerja membentuk suatu makna. Pertama, makna denotatif, yaitu makna yang paling nyata dari tanda. Kedua, adalah tanda konotatif yang menggambarkan interaksi yang bertemu dengan emosi dari pembaca. Ketiga adalah mitos, cara pemberian arti tentang suatu realitas.

Dalam penelitian ini, peneliti menganalisis setiap tanda yang terdapat dalam adegan yang menyelipkan produk sponsor untuk mengetahui makna yang ingin disampaikan melalui iklan tersebut. Peneliti mengidentifikasi penyisipan memberi makna literal atau bahkan membelokkan atau mengubah makna terhadap suatu objek atau konsep.

Dalam film Ayat-Ayat Cinta 2, setidaknya terdapat 16 sponsor. Gambar 3 adalah gambar logo sponsor dalam film Ayat-Ayat Cinta yang terdapat dalam credit pada bagian akhir film tersebut.

Dari 16 merek sponsor tersebut, terdapat enam merek yang tersisip dalam film dan dua produk sisipan yang bukan merek atau produk sponsor, melainkan sebagai penguat realisme dalam cerita. Gambar 4 adalah daftar merek dan/atau produk yang tersisip maupun tidak tersisip di dalam film.

Penelitian ini melihat etika dalam 


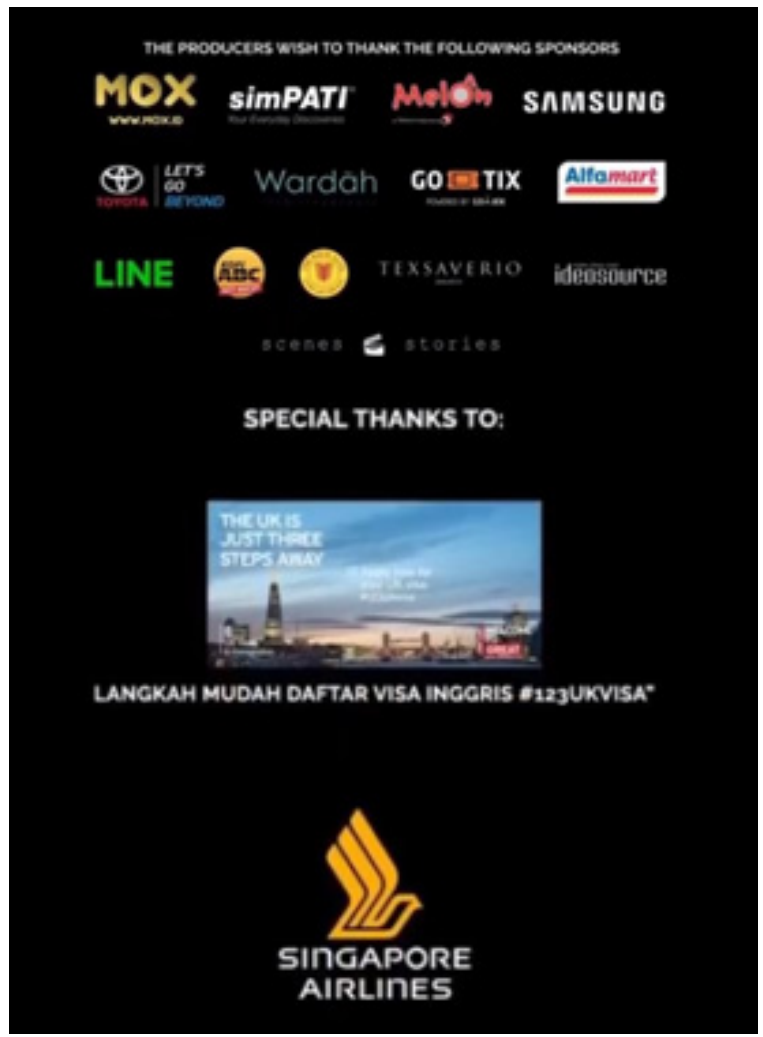

Sumber: After credit Film Ayat-Ayat Cinta 2

Gambar 3. Sponsor Film Ayat-Ayat Cinta 2

\begin{tabular}{|c|c|c|c|}
\hline No. & Merek & Jenis Produk & Tersisip/Tidak \\
\hline 1. & MOX & Sponsor & Ya \\
\hline 2. & Simpati & Sponsor & Ya \\
\hline 3. & Melon & Sponsor & Tidak \\
\hline 4. & Samsung & Sponsor & Ya \\
\hline 5. & Toyota & Sponsor & Ya \\
\hline 6. & Wardah & Sponsor & Ya \\
\hline 7. & GoTix & Sponsor & Tidak \\
\hline 8. & Alfamart & Sponsor & Tidak \\
\hline 9. & LINE & Sponsor & Tidak \\
\hline 10. & Kopi ABC & Sponsor & Tidak \\
\hline 11. & The Halal Guys & Sponsor & Tidak \\
\hline 12. & Tex Saverio & Sponsor & Tidak \\
\hline 13. & Ideosource & Sponsor & Tidak \\
\hline 14. & Scene Stories & Sponsor & Tidak \\
\hline 15. & UKVISA & Sponsor & Tidak \\
\hline 16. & Singapore Airlines & Sponsor & Ya \\
\hline
\end{tabular}

Sumber: After credit Film Ayat-Ayat Cinta 2

\section{Gambar 4. Sponsor Film Ayat-Ayat Cinta 2}

penempatan produk yang terkandung dalam setiap adegan yang menampilkan penempatan produk. Produk tersebut disisipkan secara halus atau retoris, ataukah secara eksplisit dan memaksa sehingga dapat mengganggu jalan cerita dalam film. Selain itu, peneliti juga akan membahas dari sisi hukum yang berlaku, yaitu mengidentifikasi setiap produk yang disisipkan mematuhi peraturan yang telah ditetapkan dalam Etika Pariwara Indonesia (EPI) atau ia mengaburkan batas etis pada praktik penempatan produk dalam film.

Beberapa merek dan/atau produk yang terdapat dalam film memang sebenarnya adalah sebagai penguat realisme dalam cerita. Misal, menggunakan mobil sebagai alat transportasi pribadi aktor yang menunjukkan bahwa sang aktor adalah orang dengan mobilisasi cukup tinggi karena dia seorang pengusaha dan dosen di salah satu universitas di Edinburgh. Namun, ketika memunculkan logo, bahkan tipe mobil dengan teknik pengambilan dan proporsi gambar yang kurang seimbang dapat mengalihkan perhatian penonton dari adegan atau dialog yang sedang berjalan dengan lebih terfokus membaca tipe jenis mobil yang berada tepat di belakang aktor.

Khalayak juga perlu mengetahui mitos apa saja yang terkandung dalam setiap adegan agar dapat membedakan mana suatu realitas atau kebohongan dalam melakukan penempatan produk. Mitos sangat penting karena mitos merupakan pesan atau tuturan yang tidak dapat dibuktikan, tetapi yang diyakini kebenarannya. Begitu pula tentang 
etis atau tidaknya suatu penempatan produk dalam film ini. Misal, positioning produk tidak sesuai dengan realitanya, seperti bedak Wardah yang digunakan oleh Hulya, seorang warga negara Jerman yang menggunakan bedak Wardah ketika ia berada di London. Tentu saja hal ini menimbulkan miskonsepsi mengenai produk Wardah itu sendiri sehingga bisa saja penonton mengidentifikasi produk Wardah hanya sebatas "digunakan" oleh wanita muslim yang muda dan cantik" dan "orang Jerman juga menggunaka produk Wardah" yang pada kenyataannya Wardah hanya didistribusikan di Indonesia dan Malaysia.

Oleh karena itu, peneliti mengupas pada adegan apa saja yang memiliki makna terselubung dari penempatan produk dengan membedakannya menjadi tiga makna, yaitu denotatif, konotatif, dan mitos. Namun pada akhirnya, makna yang berubah dari hanya sebagai penguat realisme cerita dalam film menjadi wujud ngiklan akan dibahas pada bagian makna mitos. Penulis akan membuktikan bagaimana mitos ini tersembunyi di balik representasi dengan cara yang samar.

Makna Denotatif, dalam pemikiran Barthes, merupakan makna yang paling nyata dari sebuah tanda atau dapat dikatakan sebagai hubungan antara tanda dan isi yang sederhana. Pemaknaan secara denotatif juga dapat menyamarkan batas etis beriklan dalam film jika makna dan konteks di mana produk itu dimunculkan tidak saling berkaitan Meskipun ia tidak melanggar ketetapan hukum secara langsung, tetapi ia melanggar tata cara dalam melakukan persuasi kepada penonton. Hal ini dikarenakan pemaknaan denotatif dapat dilakukan secara langsung dan penonton sadar bahwa dirinya adalah objek dari iklan yang sedang menerpanya lewat film. Beberapa penempatan produk yang secara denotatif mengaburkan batas etis beriklan dapat dilihat dari gambar 5 .

Meskipun gambar 5 bertujuan untuk menampilkan kegiatan akses informasi melalui jejaring online, tetapi kita dapat melihat secara langsung merek yang terdapat pada media elektronik, yang dalam hal ini adalah sebuah tablet bermerek Samsung. Penonton dapat langsung mengidentifikasi produk tersebut sebagai suatu otentik yang terdapat dalam iklan. Ketika penonton menyadari kehadiran produk, pada saat itu juga terjadi pengalihan fokus dari isi cerita kepada produk sisipan.

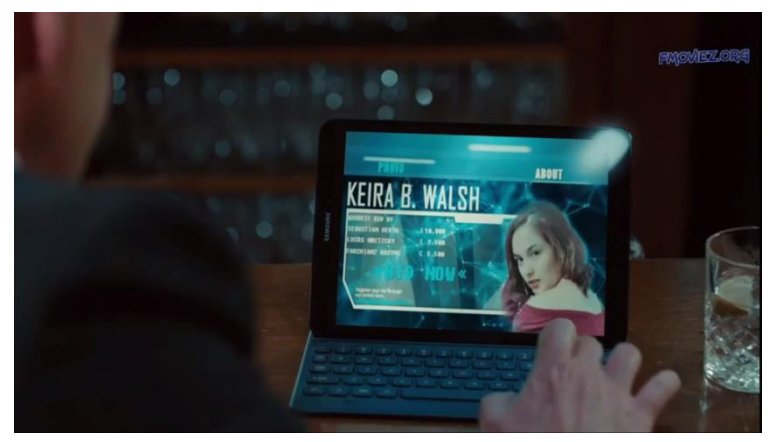

Sumber: Film Ayat-Ayat Cinta

Gambar 5. Placement Samsung Tab 


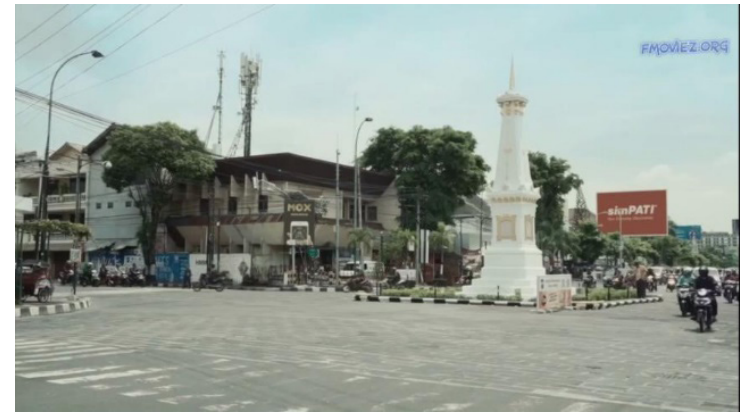

Sumber: Film Ayat-Ayat Cinta 2

\section{Gambar 6. Placement Simpati dan MOX}

Walaupun sebagian besar penempatan produk dalam film ini termasuk implicit product placement, yaitu produk atau logo hanya ditampilkan tanpa pemunculan fungsi produk dan masih pada dimensi visual, kemunculan produk ini dapat dimaknai secara eksplisit dan mengaburkan batas etis dalam iklan. Contoh penempatan produk yang secara denotatif yang juga dapat mengaburkan antara isi dan praktik iklan dapat dilihat dari cuplikan pada gambar 6 .

Cuplikan adegan pada gambar 6 secara gamblang menampilkan iklan Simpati dan MOX. Kita dapat secara objektif merasakan dan menilai makna dari iklan yang ditampilkan dalam film. Oleh karena itu, penyisipan Simpati dan MOX langsung diidentifikasi sebagai iklan dalam iklan, yaitu iklan yang mana dalam konteks cerita digambarkan sebagai iklan luar ruang menjadi sebuah sisipan dalam film.

Produk lainnya yang secara denotatif dianggap sedikit mengganggu, yaitu produk Wardah dalam film Ayat-Ayat Cinta 2 (lihat gambar 7). Produk ini langsung dapat diidentifikasi sebagai salah satu cara promosi produk tersebut karena kemunculan produk yang tidak secara langsung berkaitan dengan plot yang sedang berjalan.

Penempatan beberapa produk yang telah dijelaskan oleh peneliti memiliki makna eksplisit, meskipun ia termasuk dalam jenis iklan yang implisit. Makna eksplisit dan implisit ini seolah berseberangan jika kita pahami secara harfiah.

Namun, pada kenyataannya penempatan implisit juga dapat menampilkan produk secara eksplisit jika produk atau merek tersebut penempatannya terlalu ditonjolkan dan mengalihkan fokus cerita. Kemunculan produk secara denotatif ternyata bukan hanya sekadar membuat penonton sadar akan kehadiran produk, tetapi juga akan menimbulkan makna yang berbeda. Makna yang terbentuk tergantung dari penerimaan penonton dengan nilai-nilai serta latar belakang yang mendasari pemaknaan para penonton.

Penerimaan dan pemahaman dari

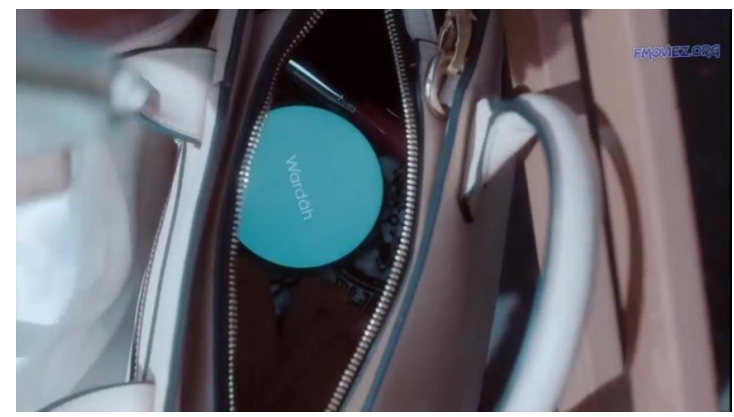

Sumber: Film Ayat-Ayat Cinta 2

Gambar 7. Placement Wardah 
penempatan suatu iklan dalam film tergantung dari penonton yang ditargetkan oleh produsen film. Tidak semua penempatan produk dianggap buruk. Penempatan produk secara denotatif dinilai baik, jika produsen film mempertimbangkan kemampuan penonton dalam menerima tanda tanpa mengabaikan etika, estetika, dan logika penempatannya dalam film.

Suatu iklan yang baik adalah iklan yang menampilkan dua faktor penting, yaitu etis dan estetis. Suatu iklan dikatakan etis ketika ia menampilkan kejujuran, kepantasan, dan tidak bertentangan dengan norma-norma yang berlaku. Sedangkan iklan dapat dikatakan mengandung nilai estetis ketika iklan memilki nilai seni tinggi untuk mengundang daya tarik calon konsumen.

Iklan tersisip atau penempatan produk yang telah diuraikan oleh peneliti memperlihatkan bahwa ada beberapa yang kurang pantas. Pantas dalam hal ini diartikan sebagai ketidaksesuaian antara kenyataan dan apa yang digambarkan dalam film. Sebenarnya yang menjadi masalah dalam penempatan produk pada film ini terletak pada ketidaksesuaian setting dan fakta produk.

Berdasarkan Etika Pariwara Indonesia (Dewan Periklanan Indonesia, 2014) mengenai ketentuan penempatan produk butir 4.14 menyebutkan bahwa, " Pemaduan produk (product placement/integration) segala ketentuan pada bagian-bagian isi, ragam, pemeran, dan wahana iklan, juga berlaku bagi periklanan penempatan produk". Hal ini berarti praktik ini juga harus mematuhi pedoman etika yang telah diatur oleh EPI. Pedoman etika (code ethics) periklanan ini terdiri dari dua tatanan pokok, yaitu tata krama (code of conducts) atau tatanan etika profesi dan tata cara (code of practices) atau tatanan etika usaha.

Dalam praktiknya, etis atau tidaknya suatu penempatan produk bukan hanya berdasarkan hukum atau peraturan tertulis, tetapi berdasarkan nilai moral yang berkembang di masyarakat. Etika dalam konteks ini adalah masalah benar atau salah, atau tindakan moral yang berkenaan dengan setiap aspek komunikasi pemasaran. Etika dan moralitas akan digunakan secara bergantian dan dianggap sinonim dengan perkataan, seperti kejujuran, kehormatan, kebaikan, dan integritas dalam komunikasi pemasaran (Shimp, 2000)

Peraturan penempatan produk juga terdapat dalam ketentuan iklan tersisip pada butir 2.29.1 menyebutkan bahwa, "Boleh dilakukan selama tidak disembunyikan atau disamarkan sehingga khalayak dimungkinkan untuk secara jelas mengidentifikasinya sebagai iklan”. Butir ini berkaitan dengan makna denotatif pada suatu adegan dalam film. Namun, pernyataan ini memunculkan sebuah dilema ketika dikaitkan dengan nilai estetika. 
Selain etika, etis atau tidaknya penempatan produk juga dapat dilihat dari segi estetikanya. Estetika mempersoalkan dan menyelidiki hakikat, dasar, dan ukuran pengalaman keindahan. Oleh karena itu, ketika memasukkan produk sisipan harus melihat dari segi kepantasannya. Apakah penempatan produk dalam film terlalu terlihat "ngiklan" atau terlihat menyatu dengan baik dengan jalan cerita.

Film merupakan suatu karya seni yang dituangkan dalam bentuk audio- visual yang memiliki sebuah alur cerita sehingga dapat menarik perhatian penonton. Bukan hanya berdasarkan alur cerita sebuah film dapat dikatakan bagus, tetapi dibantu dengan aktor, lokasi, teknik pengambilan gambar, dan proses editing yang mumpuni. Jika di dalam sebuah film dimasukkan hal-hal yang tidak berkaitan, apalagi cukup menonjol yang dapat mengganggu penonton ketika sedang menikmati jalan cerita, maka nilai estetis telah diabaikan dalam pembuatan film ini.

\section{Makna Konotatif berkaitan langsung} dengan kapan produk itu muncul, dalam adegan seperti apa, dan bagaimana penempatannya. Dengan demikian, kita nantinya akan mengetahui alasan dan maksud tertentu mengapa produk tersebut dimasukkan ke dalam suatu adegan tertentu.

Konotasi, walaupun merupakan sifat asli tanda, membutuhkan keaktifan pembaca agar dapat berfungsi sebagaimana mestinya. Oleh karena itu, setiap pemaknaan tanda bukan berasal dari tanda itu sendiri, melainkan bagaimana emosi, budaya, dan nilai yang sudah tumbuh bersama pembaca.

Akar dari kritik tentang etis atau tidaknya sebuah penempatan produk adalah ketika iklan di dalamnya cenderung menggambarkan kelompok tertentu dengan cara yang sempit dan mudah ditebak. Untuk mengetahui sejauh mana suatu penempatan iklan dapat mereduksi isi film, maka dapat dilakukan dengan cara melihat iklan tersebut secara konotatif.

Makna konotatif penempatan produk dikatakan menjadi pengabur dalam film jika makna adegan yang disisipi produk sponsor mengalami perubahan atau pembelokan makna dari konteks cerita yang sesungguhnya. Hal ni juga dapat terjadi ketika iklan salah merepresentasian sebuah produk dan konsumen atau penonton mempercayainya sebagai representasi yang benar.

Sebenarnya praktik product placement diperbolehkan, asalkan mengikuti aturan-aturan yang tercantum dalam Etika Pariwara Indonesia (EPI), terutama pada butir 4.14 tentang penempatan produk yang berbunyi: "Pemaduan produk (product placement/integration) segala ketentuan pada bagian-bagian isi, ragam, pemeran, dan wahan iklan, juga berlaku bagi periklanan penempatan produk," yang berarti 
ketentuan untuk produk yang disisipkan juga harus memerhatikan tata krama dan tata cara beriklan.

Hal yang perlu digarisbawahi dalam penelitian ini adalah adanya peran pembaca. Konotasi, walaupun merupakan sifat asli tanda, membutuhkan keaktifan pembaca agar dapat berfungsi. Oleh karena itu, setiap pemaknaan tanda bukan berasal dari tanda itu sendiri, melainkan bagaimana emosi, budaya, dan nilai yang sudah tumbuh bersama pembaca.

Penelitian ini bertujuan ingin melihat representasi penempatan produk sebagai bentuk kaburnya batas etis, berikut adalah beberapa cuplikan yang secara konotatif memiliki maksud tertentu.

Munculnya kardus Milky, produk asal Indonesia dalam salah satu adegan film AyatAyat Cinta 2 pada gambar 8 dapat menjadi salah satu tanda konotatif yang nantinya akan melahirkan sebuah mitos. Pada hasil penelitian, dijelaskan bahwa penanda konotatif yang terbentuk dari adegan ini adalah penjualan

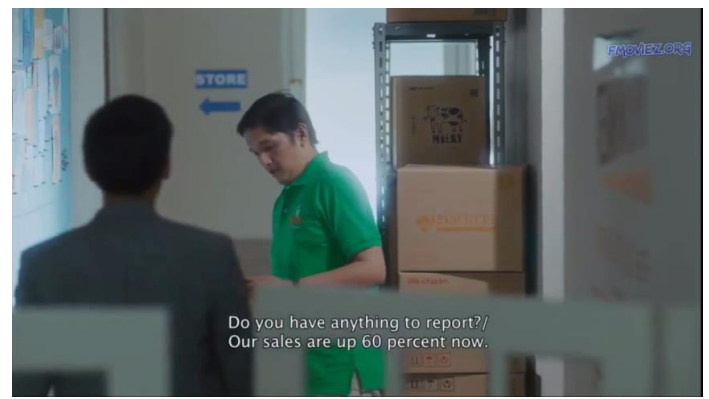

Sumber: Film Ayat-Ayat Cinta 2

Gambar 8. Placement Milky

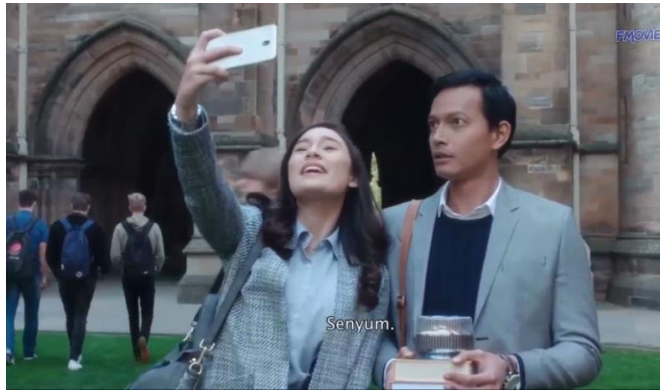

Sumber: Film Ayat-Ayat Cinta 2

\section{Gambar 9. Placement Samsung (1)}

produk Indonesia naik sebesar $60 \%$. Makna ini adalah cikal-bakal yang menggiring makna ke mitos karena mengenarilisasikan kuantitas menjadi tolak ukur sebuah kualitas. Makna ini disebut kuantifikasi kualitas, di mana kualitas direduksi ke kuantitas, termasuk semua tingkah laku manusia, realitas sosial, serta politik direduksi kepada penukaran nilai. Karena penjualan di minimart Fahri naik sebesar $60 \%$, makna yang tersirat seolah-olah produk Indonesia diterima dan digemari oleh masyarakat Edinburgh karena penjualan yang sangat baik.

Selain produk di atas, film Ayat-Ayat Cinta 2 cukup banyak menyisipkan produk Samsung, baik itu jenis tablet ataupun ponsel pintar. Dari beberapa adegan tersebut, scene ke-15 dalam film Ayat-Ayat Cinta 2 memiliki makna konotatif bahwa ponsel pintar dapat digunakan untuk berswafoto dan bertelepon.

Jika kita kaitkan dengan konteks cerita, ponsel pintar ini seolah secara samar mengambil alih cerita tentang pertemuan Hulya 


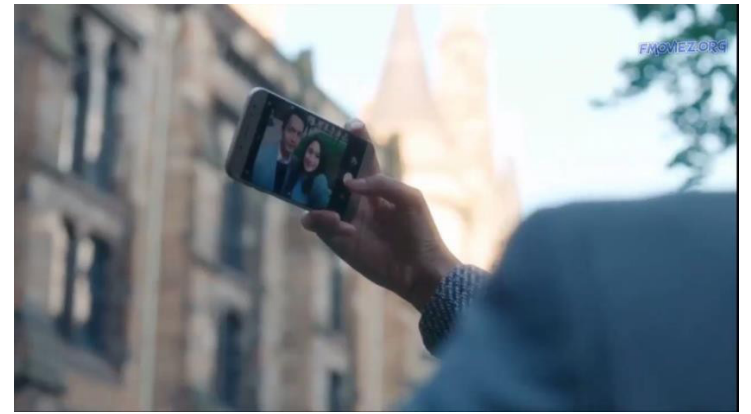

Sumber: Film Ayat-Ayat Cinta 2

Gambar 10. Placement Samsung (2)

dan Fahri menjadi iklan Samsung. Kehadiran ponsel terlalu tiba-tiba dan intens untuk satu adegan, yaitu berswafoto berulang kali dengan menampilkan merek Samsung dari bagian belakang dan depan, hingga cara memegang ponsel yang memperlihatkan merek Samsung setelah Fahri menerima telepon.

Penempatan produk pada gambar 9 dan 10 tidak mengikuti tata krama dan tata cara beriklan karena menampilkan produk Samsung secara gamblang dan berulang. Hal ini tidak sesuai dengan EPI pada butir 4.14 bahwa penempatan produk tidak boleh membuat rancu sebuah jalan cerita dalam film.

Mitos bukanlah suatu kebohongan, tetapi naturalisasi dan pendangkalan terhadap objek, konsep, dan sejarah. Pikiran Barthes dalam masyarakat moderen, mitos adalah suatu kebenaran yang dipercaya, tetapi kebenarannya belum tentu dapat dibuktikan kebenarannya.

Iklan merupakan suatu kebohongan yang dilegalkan. Ia dilegalkan karena diatur dalam peraturan dan ketetapan yang sudah disahkan secara hukum. Namun, apabila iklan dikaitkan dengan etika, maka iklan tersebut harus bertanggung jawab dan tidak menyesatkan dalam membentuk opini atau pemikiran dari objek iklan itu sendiri.

Dalam product placement, mitos akan menjadi pengabur batas etis beriklan dalam film ketika informasi dan positioning produk yang ditampilkan dalam film tidak sesuai dengan informasi dan fakta produk yang sebenarnya dan dipercaya sebagai sebuah realitas.

Mitos pada penempatan produk digunakan untuk memperkuat atau membentuk citra produk yang hidup di tengah masyarakat melalui adegan-adegan dalam film. Dengan demikian, akan muncul suatu kepercayaan para penonton terhadap merek atau produk.

Etika normatif merumuskan prinsip-prinsip etis yang dapat dipertanggungjawabkan dengan cara rasional dan dapat digunakan dalam praktik (Bertens, 2011, 20). Dengan demikian, penulis mengaitkan perspektif ini dengan bagaimana praktik penempatan produk dipandang sebagai suatu pelanggaran nilai etis dalam beriklan.

Produk Wardah adalah kosmetik yang identik dengan wanita muslim. Dan pada film ini digambarkan bahwa salah satu tokohnya, Hulya, seorang muslim juga menggunakan produk ini. Namun, terdapat beberapa minkonsepsi makna terkait fakta produk. Pertama, terkait ketersediaan produk. Faktanya, 


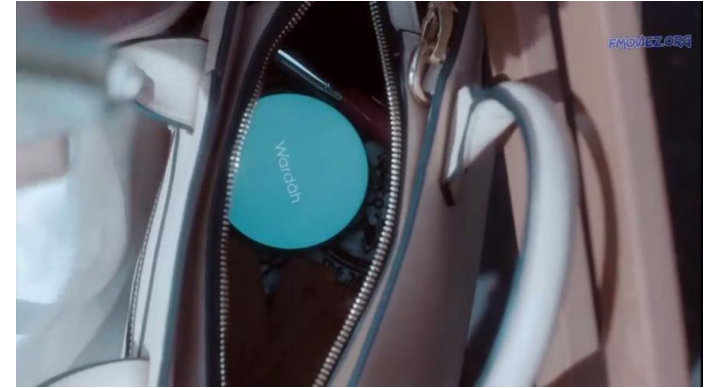

Sumber: Film Ayat-Ayat Cinta 2

\section{Gambar 11. Placement Wardah}

produk pada gambar 11 hanya didistribusikan di Indonesia dan Malaysia, sedangkan setting film ini adalah Edinburgh, Skotlandia. Bukan hanya itu, tokoh perempuan ini adalah seorang warga negara Jerman, tetapi ia menggunakan produk Indonesia. Selain itu, terdapat pendangkalan makna di mana produk yang dikenal sebagai kosmetik halal ini dimaknai hanya diperuntukkan kepada wanita muslim.

Mengingat uraian mengenai mitos produk Wardah, peneliti kembali mereduksi makna yang terdapat dalam adegan yang menyisipkan iklan Simpati dalam film Ayat-Ayat Cinta 2 dalam mitos. Pada tataran mitos, Simpati menggunakan film sebagai tempat membangun mitos tentang kualitas produknya.

Sisipan produk pada gambar 12 bermaksud untuk menanamkan mitos kepada penonton. Seperti tagline milik Simpati, "Your Everyday Discoveries" menunjukkan bahwa Simpati itu sebagai jalan keluar dari apa yang penonton cari atau inginkan, tentu saja terkait manfaat produk dalam realita.

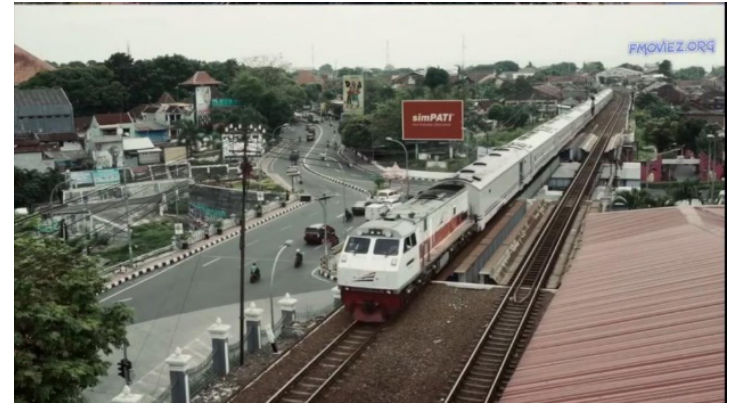

Sumber: Film Ayat-Ayat Cinta 2

Gambar 12. Placement Simpati

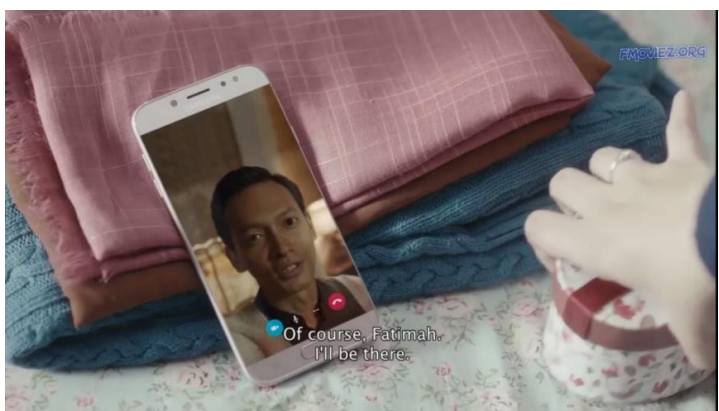

Sumber: Film Ayat-Ayat Cinta 2

\section{Gambar 13. Placement Samsung}

Berbicara tentang mitos yang ingin dibentuk oleh suatu produk, Samsung kembali hadir dalam tataran mitos. Selain muncul pada makna konotatif, Samsung secara tidak langsung ingin membuat penonton sadar akan positioning produknya. Jika dikaitkan dengan tokoh dan isi cerita dalam film Ayat-Ayat Cinta 2, maka Samsung memposisikan produknya sebagai produk yang digunakan oleh golongan menengah dan menengah ke atas (lihat gambar 13).

Sama halnya dengan Samsung, Singapore Airlines sebagai sponsor film Ayat-Ayat Cinta 2 pada gambar 14 juga untuk membangun mitos mereknya. Tagline Singapore Airlines, 


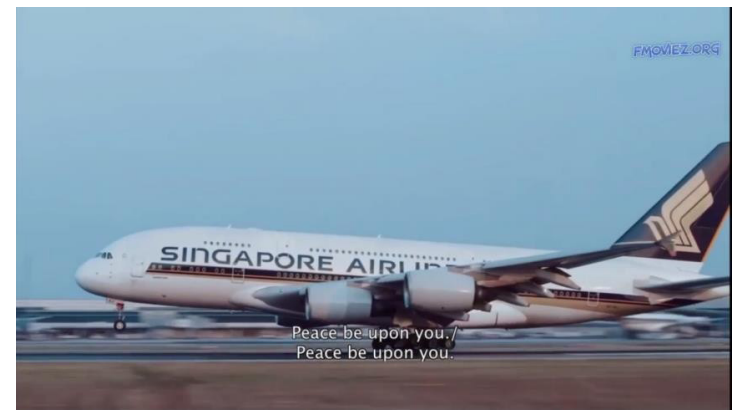

Sumber: Film Ayat-Ayat Cinta 2

\section{Gambar 14. Placement Singapore Airlines}

"A Great Way To Fly" dan sebagai maskapai dengan pelayanan terbaik di dunia pada April 2018, serta korelasinya dengan keluarga Fahri yang kaya raya, Singapore Airlines ingin menekankan bahwa ia adalah maskapai terbaik pilihan orang-orang golongan menengah ke atas.

Berdasarkan produk dan/atau merek yang telah diuraikan oleh penulis, yang ditakutkan di sini adalah ketika mitos itu berkembang menjadi realitas yang diyakini oleh penonton. Pada kenyataannya, tidak semu penonton, yang dalam hal ini adalah konsumen, mempunyai standar kemampuan menyerap informasi secara sama. Meskipun kenyataannya memang sulit untuk membuat suatu iklan yang dapat dimengerti secara umum dan sama, apalagi iklan di dalam flm, tetapi produsen film dan pengiklan harusnya menempatkan produk sesuai dengan fakta dan realitanya, bukan memaksakan suatu produk dan/atau merek masuk ke dalam adegan yang nantinya akan membuat persepsi baru terhadap produk dan/atau merek tersebut.
Etika Pariwara Indonesia (EPI) pada butir 4.4.8 menyebutkan bahwa, "Penayangan pesan penaja secara tersisip dalam film utama hanya dapat dilakukan jika informasi tentang adanya penajaan itu sudah disampaikan sejak awal penayangan film tersebut". Butir ini jelas berisi tentang kewajiban praktisi perfilman untuk menginformasikan bahwa adanya iklan sisipan di dalam film agar penonton atau audiens sadar bahwa penempatan tersebut hanyalah sebuah iklan, bukan sesuatu yang dapat diasosiasikan dengan realita film.

Relatif mudah untuk mendefinisikan etika, tetapi sulit untuk mengidentifikasi apa yang etis atau tidak etis dalam komunikasi pemasaran, salah satunya dalah beriklan (Shimp, 2000:9293). Dalam komunikasi pemasaran tentu saja mengutamakan segmenting, targeting, dan positioning. Salah satu unsur yang menjadi perdebatan adalah ketika maksud dari penempatan produk dalam film sematamata hanya untuk memudahkan pengiklan menargetkan audiens sesuai dengan pasarnya. Praktisi pemasaran yang berpengalaman telah menerima adanya pembenaran strategis mengenai target marketing. Namun, ada kemungkinan bahwa beberapa kasus dari targetting yang dikhawatirkan tidak memenuhi kebutuhan dan keinginan konsumen, melainkan hanya merupakan eksploitasi terhadap kelemahan konsumen sehingga target marketer 
dapat menang sedangkan masyarakat kalah. Di sinilah tersisa masalah etika yang tidak dapat dipecahkan hanya dengan sebuah klaim bahwa targetting adalah pemasaran yang sangat bagus.

Berdasarkan penjelasan mengenai makna denotatif, konotatif, dan mitos beserta kaitannya dengan etika dalam beriklan memperlihatkan bahwa product placement adalah suatu hal yang wajar, bahkan dibutuhkan dalam membantu produksi secara finansial dan penguat realisme dalam film. Tetapi, ketika penanda dan petanda menunjukkan tanda yang berbeda dengan konteks cerita, maka di sana terdapat pergeseran makna. Pergeseran makna inilah yang menjadi pengabur etika iklan dalam film sehingga ia bisa dikatakan sebagai praktik yang tidak etis.

Dalam pemaknaanini, bukan hanya penanda dan petanda yang bekerja, tetapi pemikiran dari penontonlah yang menilai sejauh mana makna yang dipahaminya. Apakah pada tataran pertama saja, denotatif, batas etis itu sudah terasa dilanggar, atau bahkan ia harus masuk ke tataran kedua, mitos, untuk menguak berbagai maksud yang ingin disampaikan dalam praktik penempatan produk ini, seperti membangun dan mengembangkan mitos produk yang sudah tumbuh di benak masyarakat.

Jika dilihat dari sejarah dan kebudayaan masa lalu, budaya visual masyarakat Indonesia belum terlalu bagus karena tradisi lisan di Indonesia masih kuat. Jadi, setiap ada penyisipan produk, setidaknya ada tambahan unsur audio agar ada redundansi yang dirasakan. Selain itu, pemaknaan juga dapat dilihat dari segmentasi pasar tersebut. Dengan begitu, kita dapat mengetahui nilai apa saja yang sudah ada di dalam dirinya dan bagaimana ia akan mengidentifikasi serta mengasosiasikan kehadiran produk, film, dan dirinya.

Iklan dianggap para praktisinya amat bertanggung jawab terhadap segala kejadian, baik di dalam hidup dan dikritik oleh lawan mereka sebagai penyebab sebagian besar hal yang buruk. Berikut adalah alasan yang jelas mengapa iklan begitu mendapat kritikan tajam:

"Sebagai suara teknologi, (periklanan) diasosiasikan dengan berbagai ketidakpuasan di tingkat industri. Sebagai suara dari kebudayaan massal, ia mengundang kritikan para intelektual. Dan sebagai penjelmaan yang paling terlihat dari kapitalisme, ia telah menyediakan tidak kurang dari sebuah kekuatan bagi kritik sosial.”

Praktik ini memang tidak jauh dari kapitalisme yang masih saja melandasi bagaimana industri perfilman dan periklanan berjalan. Demi keuntungan yang mereka dapatkan, para praktisi ini berusaha untuk melakukan praktik product placement dengan mencari berbagai celah agar terkesan tidak melanggar kode etik periklanan. Hal inilah yang disayangkan dari praktik product placement. Meskipun peneliti memaparkan beberapa 
contoh product placement dan menjelaskan mengapa mereka dikatakan tidak etis, tetapi perlu diingat bahwa tidak semua praktik product placement sepenuhnya dapat dikatakan tidak etis. Realisme yang dibangun dari produk yang nyata mampu memperkuat narasi dari film dan menjadi nilai tambah bagi adegan dalam film. Product placement dengan asosiasi yang tepat terhadap konteks tertentu, periode waktu, atau setting wilayah juga akan menambah otentitas dari film. Product placement dianggap tidak etis apabila ada penonjolan yang berlebihan, penempatan pada plot hingga produk memegang peran penting yang tidak sesuai, atau pemaksaan kemunculan produk yang mengalihkan cerita atau narasi film dan justru terlihat sebagai adegan tidak relevan yang mengganggu.

\section{SIMPULAN}

Dari hasil dan pembahasan dan penelitian yang telah diuraikan oleh peneliti, ada beberapa hal yang dapat disimpulkan bahwa makna denotatif merupakan makna yang paling nyata dalam tanda. Pada praktik product placement, makna denotatif merupakan makna yang paling eksplisit sehingga penonton dapat menyadari kehadiran sisipan produk secara sadar dan objektif. Walaupun sebagian besar penempatan produk dalam film ini termasuk implicit product placement, di mana produk atau logo hanya ditampilkan tanpa pemunculan fungsi produk.
Kemunculan produk secara denotatif ternyata bukan hanya sekadar membuat penonton sadar akan kehadiran produk, tetapi juga akan menimbulkan makna yang berbeda. Makna yang terbentuk tergantung dari penerimaan penonton dengan nilai-nilai serta latar belakang yang mendasari pemaknaan para penonton. Ketika makna dan konteks tidak berkaitan, maka hal tersebut berarti batas etis beriklan dalam film menjadi kabur.

Sedangkan makna konotatif berkaitan langsung dengan kapan produk itu muncul, dalam adegan seperti apa, dan bagaimana ia ditempatkan. Peran pembaca sangat berpengaruh dalam membentuk makna konotatif.. Konotasi, walaupun merupakan sifat asli tanda, membutuhkan keaktifan pembaca agar dapat berfungsi. Oleh karena itu, setiap pemaknaan tanda bukan berasal dari tanda itu sendiri, melainkan bagaimana emosi, budaya, dan nilai yang sudah tumbuh bersama pembaca.

\section{Praktik product placement dalam film} Ayat-Ayat Cinta 2 akan membuat kabur batas etis beriklan dalam film ketika makna adegan yang disisipi oleh produk sponsor mengalami perubahan atau pembelokan makna dari konteks cerita yang sesungguhnya. Atau dapat dikatakan pemaknaan terhadap sebuah adegan tidak lagi pada konteksnya, tapi pada praktik product placement- nya. Bukan hanya itu, pengaburan makna juga dapat terjadi ketika iklan salah 
merepresentasikan sebuah produk dan penonton mempercayainya sebagai representasi yang benar.

Mitos pada praktik product placement terbentuk ketika terjadi pemaknaan oleh penonton. Mitos terjadi ketika makna konotatif dipercaya kebenarannya. Dalam penempatan produk, mitos digunakan untuk memperkuat atau membentuk citra produk yang hidup di tengah masyarakat melalui adegan-adegan dalam film. Dengan demikian, akan muncul suatu kepercayaan para penonton terhadap merek atau produk. Dalam product placement, mitos akan menjadi pengabur batas etis beriklan dalam film ketika informasi dan positioning produk yang ditampilkan dalam film tidak sesuai dengan informasi dan fakta produk yang sebenarnya dan dipercaya sebagai sebuah realitas. Oleh karena itu, ketika melakukan penyisipan produk dalam film, sebaiknya lakukan penyesuaian antara fakta produk dan keterkaitannya dengan adegan film.

Penerimaan dan pemahaman dari penempatan suatu iklan dalam film tergantung dari penonton yang ditargetkan oleh produsen film. Tidak semua penempatan produk dianggap buruk. Penempatan produk secara denotatif dinilai baik, jika produsen film mempertimbangkan kemampuan penonton dalam menerima tanda tanpa mengabaikan etika, estetika, dan logika penempatannya dalam film.

Sebagai praktisi komunikasi, khususnya dalam perfilman Indonesia, pihak rumah produksi sebaiknya memikirkan produkproduk yang sesuai dengan konteks cerita serta integrasi yang tepat antara produk dan cerita sehingga tidak memunculkan pembelokan makna terhadap isi film. Selain itu, apabila terdapat produk sponsor dalam film, sebaiknya ditampilkan dan diinformasikan terlebih dahulu kepada penonton sebelum film dimulai. Hal ini terkait peraturan dalam Etika Pariwara Indonesia (EPI) tentang media bioskop pada butir 4.4 .8 yang berbunyi "penayangan pesan penaja secara tersisip dalam film utama hanya dapat dilakukan jika informasi tentang adanya penajaan itu sudah disampaikan sejak awal penayangan tersebut."

\section{DAFTAR PUSTAKA}

Alex Sobur. (2006a). Analisis teks media. Bandung: Remaja Rosdakarya.

Alex Sobur. (2006b). Semiotika komunikasi. Bandung: Remaja Rosdakarya.

Bressoud, E., \& Lehu, J. (2008). Product placement in movies: questioning the effectiveness according to the spectator's viewing conditions. in F. C. Pereira, J. Veríssimo, \& P. Neijens (Eds.), New Trends in Advertising Research. Lisboa: Lisabo.

Bungin, M. B. (2011). Penelitian kualitatif. Jakarta: Kencana Prenada.

Day, L. A. (2006). Ethics in media communication: cases and controversies. 
California: Wardsworth.

Dewan Periklanan Indonesia. (2007). Etika pariwara Indonesia: tata krama dan tata cara periklanan Indonesia Cetakan ke-7. (September), 0-94.

Dewan Periklanan Indonesia. (2014). Etika pariwara Indonesia amandemen 2014. Edisi ke-2. Retrieved from http://p3i-pusat. com/wp- content/uploads/2015/11/EPI2014- Final-SK-Perubahan.pdf.

Hackley, C., \& Nappolini, M. (2008). Moviegoers'response to product placement: a mise-en-scene analysis. London: The School of Management Royal Holloway University of London.

Hidayat, D. R. (2015). Dinamika iklan pengobatan alternatif di televisi. Jurnal Kajian Komunikasi, 3(2), 112-119. https:// doi.org/10.24198/jkk.vol3n2.2.

Kumalawati, J., Leonid, W., \& Rumambi, J. (2012). Analisa sikap audience terhadap product / brand placement Apple pada film "Mission Impossible 4 (Ghost Protocol)". Jurnal Manajemen Pemasaran, 1(1), 1-7.

Lechte, J. (2001). 50 Filsuf kontemporer. Jakarta: Penerbit Kanisius.

Marketing.co.id. (2012). Film Indonesia yang "Jualan". Retrieved March 10, 2018, from website: https://marketing.co.id/filmindonesia-yang-jualan.

Mellawatie, A., Maryani, E., \& Aristi, N. (2017). Representasi laki-laki metroseksual dalam iklan vaseline men face moisturizer. Jurnal Manajemen Komunikasi, 2(1), 10-17.
Mirandha, I. Y. (2017). Perbandingan persepsi khalayak antara iklan yang mengandung humor dan tidak mengandung humor. PRofesi Humas: Jurnal Ilmiah Ilmu Hubungan Masyarakat, 1(2), 112-123.

Moleong, L. J. (2008). Metode penelitian kualitatif. Bandung: Remaja Rosdakarya.

Nuraryo, I. (2019). Kultur pop dan diskursus ideologi kecantikan pada iklan di televisi. ProTVF, 3(2), 171. https://doi. org/10.24198/ptvf.v3i2.21488.

Primalia, I. (2006). Representasi product placement dalam film "Habibie Dan Ainun" Abstrak Pendahuluan Metode Penelitian. 1-11.

Purnomo, Z. V. (2015). Product placement: Film, program televisi, video games atau musik? Jurnal Studi Manajemen, 9(1), 100-114. Retrieved from http://journal.trunojoyo. ac.id/kompetensi/article/view/1417.

Sasono, E. et al. (2011). Menjegalfilm Indonesia. $1-370$.

Shimp, T. A. (2000). Periklanan promosi dan aspek tambahan komunikasi pemasaran terpadu, edisi ke-5 jilid 1. Jakarta: Erlangga.

Shimp, T. A. (2014). Komunikasi pemasaran terpadu dalam periklanan dan promosi. Jakarta: Salemba Empat.

Tandiono, E., \& Rumambi, J. (2013). Analisa pengaruh product placement dan brand recall volvo terhadap sikap konsumen dalam film " twilight saga: breaking dawn (part 2)." Jurnal Manajemen Pemasaran, $1(1), 1-8$. 